\title{
The complete gospel: Jesus and women via the Jesus Seminar
}

\author{
Glenna S Jackson ${ }^{1}$ \\ Otterbein College, Westerville Ohio \\ Visiting Professor: University of Pretoria
}

\begin{abstract}
Playing on the title of the Jesus Seminar's first major publication, The Complete Gospels, this study uses the database of the Jesus Seminar to stitch together the story of Jesus as it appears in the gospel narratives that include women as major characters.
\end{abstract}

As a relative latecomer to this profession, I have been a Fellow in the Jesus Seminar for only five years. This means that $I$ joined the enterprise after the initial work on the sayings of Jesus, ${ }^{2}$ at the tail end of the deeds of Jesus, ${ }^{3}$ and at the beginning of another one of the enterprises called "Profiles of Jesus". My intent for this study, therefore, is to use the database myself for the first time to see what kind of profile emerges in terms of the "red and pink" stories that include women as major characters. (For those unfamiliar with the Jesus Seminar database, if a saying or deed of Jesus is regarded as historically reliable and supported by a preponderance of evidence, it is color coded red; if the information is probably reliable and fits well with other evidence that is verifiable, it is color coded pink; if the information is possible but unreliable and lacks supporting evidence, it is color coded gray [this is a tricky category because it can also mean an average vote]; if the information is improbable and does not fit verifiable evidence or is largely or entirely fictive, it is color-coded black.) My thesis is that those stories that

\footnotetext{
1 Prof Glenna S Jackson visited the University of Pretoria as research fellow of Prof Dr Andries G van Aarde, July-October 2000.

2 Robert W Funk, Roy W Hoover, and The Jesus Seminar, The Five Gospels: What Did Jesus Really Say? (New York: Macmillan, 1993).

${ }^{3}$ Funk and The Jesus Seminar, The Acts of Jesus: What Did Jesus Really Do? (HarperSanFrancisco, 1998).
} 
include women as major characters and that are color coded red and pink capture, in and of themselves, the authentically historical Jesus. While I cannot call the collection of these stories "The Gospel According to the Women", since the women presumably did not write the stories, the narrative might be dubbed "The Complete Gospel: Jesus and Women" - a wordplay on The Jesus Seminar's first book publication, The Complete Gospels. ${ }^{4}$

Before I begin the actual profile, I present an introduction with two points for consideration. The first is a weighing in once again on the debate within feminist New Testament scholarship regarding Jesus' own Judaism. ${ }^{5}$ The second point is to highlight profiles of Jesus written by other Fellows of the Jesus Seminar in order to ascertain the general picture the database offers.

As to the first point, the question is, "Are Christians guilty of placing first-century Judaism as a negative foil against the reconstruction of a liberated, feminist Jesus?" Answering this question is a difficult task because some of us want the "feminist" Jesus to serve as a critique against the Christian tradition and its subjugation of women over the past two thousand years. At the same time, we must be careful not to pit Jesus against his own Judaism of the day, a portrait that makes him and/or us sound anti-Jewish. In the worst-case scenario, Jesus (and thus, Christianity) appears to supersede Judaism. It seems to me that some options can be developed about Jesus and any part he may have played in the status and role of women in the first century: 1) Jesus as solo "feminist" egalitarian; ${ }^{7}$ 2) Jesus as exploiter of women (to affirm his own agenda on Torah and custom - a sort of in-your-face-to-the-authorities kind of guy); or 3) Jesus within a communal emancipatory Jewish framework (one that affirms the diversity as well as a

\footnotetext{
4 Robert J Miller (ed), The Complete Gospels: Annotated Scholars Version (Santa Rosa, CA: Polebridge Press, 1994).

' See Jackson, "Jesus as First-Century Feminist: Christian Anti-Judaism?", Feminist Theology 19 (September, 1998), pp 85-98.

6 "Feminist" is, of course, an anachronistic term in this context and thereby in quotation marks.

7 See Kathleen E Corley, “The Egalitarian Jesus: A Christian Myth of Origins", Forum 1,2 (Fall, 1998), pp 291-325.
} 
progressive tendency on the part of women within first-century Judaism). If we were to develop a spectrum ${ }^{8}$ using these options, it may look like this:

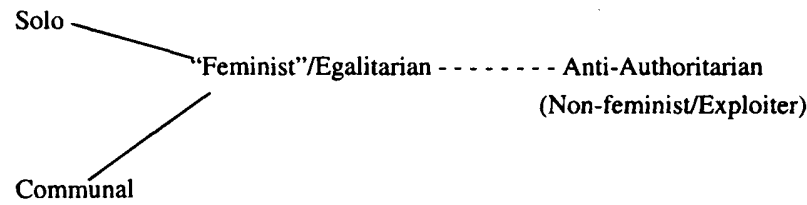

But no matter where we are with these options or on this spectrum, it is tricky to fit together the historical and situational contexts of Galilee, Judaism, Jesus' ministry, and the early church. For those of us who teach to predominantly Christian students, we want to emphasize the errors of Christianity on behalf of women without initiating or fostering anti-Semitism or anti-Judaism. I hope that I am erring on the left end of the spectrum, that is, Jesus within a communal emancipatory Jewish framework that affirms the diversity as well as a progressive tendency on the part of women within first-century Judaism.

As the second point to this introduction, I have surveyed other profiles based on the findings of the Jesus Seminar database to sample the kinds of profiles that Fellows have written over the past four years since the initial database was completed. This representation includes Charlie Hedrick's "Profile Under Construction", which sets up the task and inherent problems, and Hal Taussig's and Roy Hoover's profiles of Jesus as sage.

Charlie Hedrick includes the following eleven premises as a preface to any profile of Jesus based on the Jesus Seminar database: 1) the early Christian gospels, both canonical and non-canonical, are theological interpretations of Jesus and all information they contain serves the interest of early Christian faith in some way; 2) we have no verbatim sayings of Jesus in early Christian literature and what is attributed to Jesus has been given its present form in the early Christian movement, both in the oral period and later when the traditions had been reduced to writing; 3 ) the words attributed to Jesus in early Christian literature are the words of early Christian faith, and their description of its

Thanks to Paul A Laughlin for this suggestion. 
activities constitutes the early Christian view of how the Christ ought to comport himself; 4) we may hope to hear an echo of the voice of the historical man, and sketch in barest outline some details of his life; 5) the criterion of dissimilarity/distinctiveness is the most reliable tool in the search for the words of the historical man; 6) the findings of the Jesus Seminar constitute an irreducible minimum of the historical data; 7) it is not possible to know what Jesus thought of himself; 8 ) inferences may be made from the historical data (an inference is a reader's interpretation of data and should not be confused with the data itself); 9) the data will allow different inferences; 10) a reconstructed Jesus is not Jesus as he actually was, but Jesus at his most radical dimensions and the reconstruction, if it is reliably done, has eliminated much of what Jesus had in common with first-century Palestinian Judaism and earliest Christianity; 11) thus we can hope to see the historical man only in his most radical dimensions. ${ }^{9}$

This preface sets the scene for most of us working with the database. Hal Taussig's "Cynic Sage", for example, does not differ markedly from other now familiar portraits already painted by, among others, John Dominic Crossan, Marcus Borg, and Burton L. Mack. ${ }^{10}$ Taussig maintains that there are four strains of historical Jesus research bedrock which fit together into the sage profile: 1) the meals of Jesus, i.e., his status as a regular guest sage at meals with the disreputable which is resonant of the honor and shame codes concerning with whom one associated; ${ }^{1 /}$ 2) Jesus' "missional" instructions to his followers; 3) the relatively iconoclastic character of Jesus' core teachings; and 4) Jesus' association with "tax collectors and sinners", a popular

\footnotetext{
9 Hedrick, "Jesus of Nazareth: A Profile Under Construction", in Westar Institute Seminar Papers (Fall, 1998), pp 143-50.

10 See, for example, Crossan, Jesus: A Revolutionary Biography (HarperSanFrancisco, 1994); Borg, Jesus in Consemporary Scholarship (Valley Forge, PA: Trinity Press International, 1994); and Mack, A Myth of Innocence: Mark and Christian Origins (Philadelphia: Fortress, 1988).

" Stephen Patterson ("Jesus and the Empire of God: On Dirt, Shame, and Sin in the Expendable Company of Jesus", in Westar Institute Seminar Papers [Spring, 1997], pp 13-27) claims that Jesus is, as a result of his associations with "sinners and prostitutes", a "shameless fool". Mahlon Smith ("Israel's Prodigal Son: Reflections on Reimaging Jesus", in Westar Institute Seminar Papers [Fall, 1997], pp 65-88) goes a step further and identifies Jesus as the autobiographical "prodigal son" himself.
} 
occurrence among popular Cynics who thrived on being associated with those who were considered outsiders. $^{12}$

Roy Hoover describes Jesus similarly as a radical idealist, iconoclastic sage, and enigmatic reformer. For his evidence, he looks at the Essenes at Qumran, the Pharisees, and John the Baptist, all of whom embrace what they regarded as Israel's religious ideal as the remedy for what was wrong with Jewish religion and society in their time. He concludes that Jesus' teaching and activity can be seen as his own version of such a quest. $^{13}$

Since my specific interest is in Jesus' historical relationship to and attitude toward women, I am testing these general profiles against those pericopes where women account for part of the activity. Of the seven or eight pericopes that include women as characters in Mark's narratives and parallels, only three of them are color coded pink (verifiably historical), four are gray (doubtful or cannot really tell) and one is black (undoubtedly a construction on the part of the evangelist). In other words, the database for authentic sayings and deeds of Jesus excludes the familiar stories of Jairus' daughter, the Syrophoenician/Canaanite woman, the widow's mite, the anointing in Bethany, and the women at the tomb as being historic scenes in Jesus' life. The ones that can be found in the "historically accurate" database in Mark include the stories of Simon's mother-in-law, the bleeding woman, Jesus' family, and the witnesses at the crucifixion and burial. Matthew's story (along with Luke's and Thomas') of the woman concealing leaven in fifty pounds of flour is color coded red. The widow of Nain in Luke is black; the mention of Mary of Magdala is red while Joanna and Susanna are gray; the story of Mary and Martha arguing over household responsibilities is color coded black, as is the healing of the woman on the Sabbath. However, Luke's stories of the lost coin and the woman who demands justice from the corrupt judge are pink, and, of course, Mary is the mother of Jesus. All of the female-specific stories in John are, not surprisingly, gray or black. However, I will give special attention to Mary of Magdala via John's gospel. The

\footnotetext{
12 Taussig, "Jesus in the Company of Sages", Forum 1, 2 (1998) pp 399-429.

${ }^{13}$ Hoover, "Radical Idealist, Iconoclastic Sage, Enigmatic Reformer: A Profile of the Historical Jesus", in Westar Institute Seminar Papers (Fall, 1996) pp 1-7.
} 
remaining sayings where women can be found in Thomas are, for the most part, gray or black; the one exception is the woman with the empty jar: it is color coded pink. ${ }^{14}$

While I am not a narrative critic, I find it fascinating that if we were to string the red and pink acts and sayings of Jesus in the company of women together, one comes up with the following story, all with unexpected turns in the road within first-century Judaism:

- Mary was pregnant; she gave birth to a son [Luke 2:5, 7]. Now eight days later, when the time came to circumcise him, they gave him the name Jesus [Luke 2:21].

- Jesus was about thirty years old when he began his work [Luke 3:23a].

[And] Simon's mother-in-law was in bed with a fever, and they told him about her right away. He went up to her, took hold of her hand, raised her up, and the fever disappeared. Then she started looking after them [Mark 1:30-31; Matt 8:14-15; Luke 4:38-39].

- And it so happened soon afterward that he traveled through towns and villages, preaching and announcing the good news of God's imperial rule. The twelve were with him [maybe, i.e., gray], and also some women whom he had cured of evil spirits and diseases: Mary, the one from Magdala, [and perhaps, i.e., gray] Joanna, the wife of Chuza, Herod's steward, and Susanna, and many others, who provided for them out of their resources [Luke 8:1-3].

- And there was a woman who had had a vaginal flow for twelve years. When this woman heard about Jesus, she came up from behind in the crowd and touched his cloak. And the vaginal flow stopped instantly, and she sensed in her body that she was cured of her illness [Mark 5:25, 27, 29; Matt 9:20, 22; Luke 8:43-44].

- When the sabbath day arrived, he started teaching in the synagogue; and many who heard him were astounded and said so: "Where's he getting this?" and "What's the source of all this wisdom?" and "Who gave him the right to perform such miracles? Isn't he Mary's son? And who are his brothers, if not James,

\footnotetext{
${ }^{14}$ See Appendix for complete color-coded list.
} 
Joses, Judas, and Simon? And who are his sisters, if not our neighbors?" And they were resentful of him [Mark 6:2-3; Matt 13:54-57a].

- Jesus [said], Heaven's imperial rule is like leaven that a woman took and concealed in fifty pounds of flour until it was all leavened [Matt 13:33; Luke 13:20-21; Thom 96].

- Jesus said, The [Father's] imperial rule is like a woman who was carrying a [jar] full of meal. While she was walking along [a] distant road, the handle of the jar broke and the meal spilled behind her [along] the road. She didn't know it; she hadn't noticed a problem. When she reached her house, she put the jar down and discovered that it was empty [Thom 97].

- Or again, is there any woman with ten silver coins, who if she loses one, wouldn't light a lamp and sweep the house and search carefully until she finds it? When she finds it, she invites her friends and neighbors over and says, "Celebrate with me, because I have found the silver coin I had lost" [Luke 15:8-9].

- $\quad$ [He told them another parable]: Once there was a judge in this town who neither feared God nor cared about people. In that same town was a widow who kept coming to him and demanding: "Give me a ruling against the person I'm suing". For a while he refused; but eventually he said to himself, "I'm not afraid of God and I don't care about people, but this widow keeps pestering me. So I'm going to give her a favorable ruling, or else she'll keep coming back until she wears me down" [Luke 18:2-5].

- [And after performing many more miracles and teaching many more parables, many of which went against the Establishment], they seized him and held him fast [Mark 14:46; parallels]. And [the male disciples] all deserted him and ran away [Mark 14:50]. And they brought Jesus before the high priest [Mark 14:53; parallels], [and] the ranking priests bound Jesus and led him away and turned him over to Pilate, the Roman governor (Mark 15:1; parallels]. Pilate had Jesus flogged, and then turned him over to be crucified [Mark 15:14; parallels]. And the soldiers crucif[ied] him [Mark 15:24; parallels].

- Now some women were observing this from a distance, among whom were Mary of Magdala, and Mary the mother of James the younger and Joses, and Salome. 
These women had regularly followed and assisted him when he was in Galilee, along with many other women who had come up to Jerusalem in his company [Mark 15:40-41; Matt 27:55-56; Luke 23:49].

- [And later], Mary of Magdala goes and reports to the disciples [what she has seen in a vision], "I have seen the Master", and relates everything he had told her [John 20:18].

The first unexpected turn in the road is, of course, a pregnant unmarried woman. ${ }^{15}$ The story continues after Jesus grows up and begins performing miracles. Of the briefest

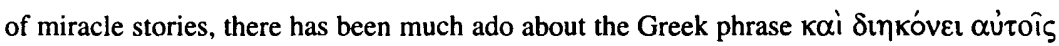
(and she served them), with the possibility that Simon's mother-in-law may have been given some sort of official capacity within the early church (an unexpected fork in the road, to be sure, but one that the evangelists take, not the historical Jesus), and, more importantly, further ado about the female specificity of the character who is healed, especially if women were not in fact particularly esteemed.

Jesus continues with more turns in the road by curing more women, with special mention of the woman who had been bleeding for twelve years. (In a previous article, I caution us to avoid jumping to the conclusion that this is necessarily a breaking of the purity code.) ${ }^{16}$ The importance of the story in this instance is her female specificity and a cure.

In the next pericope, while the crowds are wondering where Jesus gets his authority, the composition of his family is confirmed once again with an apparent fatherless household, but one that includes the name of the mother and the mention of sisters.

And what were the teachings? The Jesus Seminar affirms the centrality of God's imperial rule. And according to the Fellows, the parable of the leaven "transmits the

\footnotetext{
is Dov Dushan, an Israeli tour guide, offers a common-sense approach to the virgin birth: when the early teen-aged Mary told her orthodox parents that she was pregnant and that it was a miracle because she had not had sexual relations with anyone, they did what most of us would do - believe in the miracle rather than have her stoned to death!

16 Jackson, "Jesus as First-Century Feminist".
} 
voice of Jesus as clearly as any ancient record can". ${ }^{17}$ It is of note that Jesus, according to Matthew, adheres to the custom of not using God's name and thus says, "heaven". (Luke refers to the imperial rule as God's and Thomas refers to it as the Father's.) But while Jesus honors the avoidance of God's name in Matthew, he provides three turns in the road by surprising his audience with reverse interpretations of traditional imagery in the parable of the leaven: 1) leaven is, of course, normally a symbol of corruption and profanity in Judaism, ${ }^{18}$ especially during Passover, and likewise in Hellenistic cultures. Jesus, therefore, uses the image as an inverse and positive representation of God's imperial rule. Leaven, like the mustard weed, is a small thing that can be a very large nuisance. Such is the kingdom. ${ }^{19}$ 2) The act of "concealing" the leaven is a strange and insidious way to mix yeast and flour. However, even though the leaven has been hidden and, therefore, unseen, the rising of the bread will make it quite obvious. 3) One would also wonder why the woman was baking so much bread, i.e., fifty pounds of flour worth. It is undoubtedly an echo of Sarah in Genesis 18 , who bakes cakes of fifty pounds of flour to give to her heavenly visitors after hearing that in her old age, she is to bear a son: "Fifty pounds of flour, it seems, is a suitable quantity to celebrate an epiphany - a visible, though indirect, manifestation of God". ${ }^{20}$

The parable of the empty jar immediately follows the parable of the leaven in Thomas and, in contrast to the woman baking bread, the woman with the empty jar is not attentive or purposeful, and therefore, the Father's imperial rule slips away. Some of the Fellows judge the parable of the empty jar to be a parody of the story of Elijah and the widow in 1 Kings 17:8-16. For our purposes, the woman's inattentiveness points to another turn in the road: that is, God's domain is unnoticed, perhaps invisible, unexpected, and modest. And yet another parable illustrates God's imperial rule, not through the unexpected worth of a small coin to the homemaker (after all a penny was worth three

\footnotetext{
17 Funk, The Five Gospels, p 195.

${ }^{18}$ Cf Mark 8:15; Matt 16:6; Luke 12:1; 1 Cor 5:6-8.

${ }^{19}$ Stephen J Patterson, The Gospel of Thomas and Jesus (Sonoma, CA: Polebridge, 1993) p 240.

${ }^{20}$ Funk, The Five Gospels, p 195.
} 
small pieces of candy even in my childhood), but through the joy she expresses when she finds that which was already there.

The intriguing story of the persistent widow, a kind of person who is at least stereotyped in the first century as poor and helpless, is the farthest away from the center of economic, social, and political power. She is the last person, therefore, whom one would expect to demand - or get - justice.

While Mark 16:8 leads us to believe that the role of the women in the final events of Jesus' life was probably repressed and belittled, ${ }^{21}$ they are included earlier in Mark as witnesses to the crucifixion while the male disciples run.

And Mary of Magdala gets special attention in the gospel of John: Mary of Magdala goes and reports to the disciples, "I have seen the Master", and relates everything he had told her [John 20:18].

While this last reference to Mary of Magdala found in John 20:18 is actually color coded gray, the Fellows of The Jesus Seminar acknowledge and color red the idea that Mary was among the early witnesses to the resurrection of Jesus, that is, her claim to have had a vision of the risen Lord [Master] must be acknowledged.

And so this narrative begins with an unwed mother; jumps to Jesus' adulthood with the ordination of an older woman; includes stories of women with whom he may be breaking the purity code; contains unexpected definitions of God's imperial rule through the traditional role of women as homemakers in first-century Judaism; offers reminders of an incomplete, thus matriarchal, family; recounts stories of a demanding woman, sinners and female followers; and concludes with a female witness to the resurrected Lord - all unexpected turns in the road, to say the least. I would, therefore, add to the profiles of the "male" Fellows in the Jesus Seminar that the small core corps of women in the gospel story constitutes the entire essence of the historical Jesus: he was born to a single woman, he healed women, his most authentic teachings contain female characters and roles, he was crucified while the women watched, and Mary's vision of a resurrected Lord have remained with us for two thousand years - quite a simple history, really - in fact, the Complete Gospel.

${ }^{21}$ Funk, The Five Gospels, p 158. 


\section{WOMEN IN THE GOSPELS}

(color coding for female-specific core of stories from The Five Gospels and The Acts of Jesus)

Women in Mark (and parallels in Matthew, Luke, John and Thomas)

1. Mark 1:29-31; Matthew 8:14-15; Luke 4:38-39

Simon's mother-in-law (pink)

2. Mark 2:27-28

Sabbath observance [Adam and Eve] (pink)

3. Mark 3:31-35; Matthew 12:46-50; Luke 8:19-21; Thom 99

True relatives (pink)

4. Mark 5:21-43; Matthew 9:18-26; Luke 8:40-56

Jairus' daughter (gray) and the woman with a vaginal hemorrhage (pink)

5. Mark 6:1-6; Matthew 13:54-58

No respect at home (red)

6. Mark 6:17-29; Matthew 14:3-12; Luke 3:19-20

Herod beheads John (Herodias $=$ red; her daughter $=$ gray)

7. Mark 6:35-44; Matthew 14:13-21; Luke 9:12-17; John 6:1-15

Loaves and fish for 5,000 (black)

8. Mark 7:1-13; Matthew 15:1-9

Unwashed hands (gray)

9. Mark 7:24-30; Matthew 15:21-28

Greek woman's daughter (gray)

10. Mark 8:1-9; Matthew 15:32-39

Loaves and fish for 4,000 (black)

11. Mark 9:36-37; Matthew 18:1-6; Luke 9:46-48

Accepting a child

12. Mark 10:2-12; Matthew 19:1-12; Luke 16:18

Is divorce permitted? (gray)

13. Mark 10:13-16; Matthew 19:13-15; Luke 18:15-17; Thom 22

Children in God's domain (pink) 
14. Mark 10:18-19; Matthew 19:18-19; Luke 18:19-20

Honor your father and mother (gray)

15. Mark 10:28-30; Matthew 19:29; Luke 18:29-30

Hundredfold reward (gray)

16. Mark 12:18-27; Mathew 22:23-33; Luke 20:27-40

On the resurrection (gray)

17. Mark 12:38-40; Luke 20:45-47

Those who prey on widows (gray)

18. Mark 12:41-44; Luke 21:1-4

Widow's pittance (gray)

19. Mark 13:14-20; Matt 24:15-22; Luke 21:20-24

Time for flight [pregnant women and nursing mothers]

20. Mark 14:3-9; Matthew 26:6-13; Luke 7:36-50; John 12:1-8

The anointing (gray)

21. Mark 14:66-72; Matthew 26:69-75; Luke 22:54-62

A rooster crows [slave girl] (black)

22. Mark 15:40-41; Matthew 27:55-56; Luke 23:49; John 19:25-27

The death of Jesus (pink)

23. Mark 15:47; Matthew 27:61; Luke 23:55-56

The burial (black)

24. Mark 16:1-8; Matthew 28:1-8; Luke 24:1-11; John 20:1-18

The empty tomb (black)

\section{Women in Matthew (not in Mark)}

1. Matthew 1:1-17 - Family tree (Mary and Joseph = red)

2. Matthew 1:18-25 - Birth of Jesus (Mary and Joseph $=$ red)

3. Matthew 2:1-12 - Astrologers from the East (black)

4. Matthew 2:13-15 - Flight to Egypt (black)

5. Matthew 2:16-18 - Murder of the babies (black)

6. Matthew 2:19-23 - Return to Israel (black)

7. Matthew 5:27-28 - On lust (black) 
8. Matthew 10:34-36; Luke 12:51-53 - Peace or sword (black)

9. Matthew 10:37-39; Thomas 55, 101 - Hating one's family (gray)

10. Matthew 11:11; Luke 7:28; Thomas 46-John as prophet [born of women] (gray)

11. Matthew 11:16-19; Luke 7:31-35 - Children in marketplaces (gray)

12. Matthew 12:42; Luke 11:31 - Queen of the South (black)

13. Matthew 13:33; Luke 13:20-21; Thomas 96 - Leaven (red)

14. Matthew 18:23-35 - Unforgiving slave (pink)

15. Matthew 20:20-23 - Request for precedence [mother of the sons of Zebedee] (black)

16. Matthew 21:16 - Out of the mouths of babies

17. Matthew 21:28-32 - Two sons (black)

18. Matthew 23:37-39; Luke 13:34-35 - Jerusalem indicted (black)

19. Matthew 24:40-41; Luke 17:34-35 - Taken or left (gray)

20. Matthew 25:1-13 - Ten maidens (gray)

21. Matthew 27:15-19 -Before Pilate [wife] (black)

\section{Women in Luke (not in Mark or Matthew)}

1. Luke 1:5-6 - Family tree of John the Baptist (gray)

2. Luke 1:7-25 - Miraculous conception of John (black)

3. Luke 1:26-38 - Miraculous conception of Jesus (black)

4. Luke 1:39-56 - Mary visits Elizabeth (black)

5. Luke 1:57-80 - Birth and naming of John (red)

6. Luke 2:1-40 - Birth of Jesus (black)

7. Luke 2:41-52 - The young Jesus in Jerusalem (black)

8. Luke 4:25-27 - Widows and lepers (black)

9. Luke 7:11-17 - The widow's son at Nain (black)

10. Luke 8:1-3 - Women companions of Jesus (red and gray)

11. Luke 10:38-42 - Mary and Martha (black)

12. Luke 11:27-28; Thomas 79-Privileged womb (black)

13. Luke 13:10-17 - Cripple and the Sabbath (black)

14. Luke 15:8-10 - Lost coin (pink) 
15. Luke 17:32 - Lot's wife (black)

16. Luke 18:1-8 - Corrupt judge (pink)

17. Luke 23:26-31 - Jerusalem mourned [daughters of Jerusalem] (black)

18. Luke 24:22-35 - Witnesses (black)

\section{Women in John (not in Mark, Matthew or Luke)}

1. John 1:1-14 (cf. Proverbs 7:22-31) - Prologue (black)

2. John 2:1-12 - Marriage at Cana (black)

3. John 3:3-8 - Born of water and spirit (black)

4. John 4:1-42 - The woman at the well (black)

5. John 7:53-8:11 - First Stone Gospel (gray)

6. John 11:1-44 - The raising of Lazarus (black; Mary and Martha = gray)

7. John 19:25-27 - Mother and son (black)

Women in Thomas (not in Mark, Matthew, Luke or John)

1. Thomas 15 - Your Father (black)

2. Thomas 21 - Mary's question (black)

3. Thomas 22 - Children in God's domain (gray)

4. Thomas 53 - True circumcision (black)

5. Thomas 97 - Empty jar (pink)

6. Thomas 105 - Child of a whore (black)

7. Thomas 114 - Male and female (black) 